\title{
EFEKTIVITAS INSTAGRAM SEBAGAI MEDIA PROMOSI PADA PRODUK HIJAB DAN OUTFIT CHIC SQUARE
}

\author{
Hj. Sri Murdilah Fournawati, Dra.,M.Ikom \\ Widya Indah Mutiarani \\ Fournwati@unis.ac.id \\ Prodi Ilmu Komunikasi, FISIP Universitas Islam Syekh Yusuf Tangerang
}

\begin{abstract}
This study to determine the extent of the effectiveness of Instagram as a promotional media on hijab and chic square outfit products. To answer the purpose of this study, researchers used the theory of Uses and Gratifications. While the respondents in this study were Chic Square Instagram account followers with a sample of 100 respondents. The results of this study indicate that there is effectiveness caused by the Chic Square Instagram account as a product promotion media that is equal to $54.7 \%$, while the remaining $45.3 \%$ is influenced by other factors outside the Chic Square Instagram account not examined in the study this.
\end{abstract}

Keywords: Instagram, Chic Square, Promotion

\begin{abstract}
ABSTRAK
Penelitian ini untuk mengetahui sejauhmana efektivitas Instagram sebagai media promosi pada produk hijab dan outfit Chic Square. Untuk menjawab tujuan penelitian ini, peneliti menggunakan teori Uses and Gratifications. Sedangkan yang menjadi responden dalam penelitian ini yaitu followers akun Instagram Chic Square dengan sampel 100 responden. Adapun hasil penelitian ini menunjukan bahwa terdapat efektivitas yang ditimbulkan oleh akun Instagram Chic Square sebagai media promosi produk yaitu sebesar 54,7\%, sedangkan sisanya sebesar 45,3 \% dipengaruhi oleh faktor-faktor lain di luar akun Instagram Chic Square yang tidak diteliti dalam penelitian ini.
\end{abstract}

Kata Kunci : Instagram, Chic Square, Promosi

\section{PENDAHULUAN}

Salah satu sektor gaya hidup dan kebutuhan manusia adalah kebutuhan fashion atau pakaian.
Perkembangan trend fashion pada era modern ini sangat tinggi, khususnya bagi kaum wanita hijabers. Trend fashion ini menjadikan berkembangnya pasar 
bisnis di Indonesia, khususnya yang bergerak di bidang fashion atau pakaian. Tingkat persaingan bisnis yang sangat ketat dalam bidang fashion tersebut, menuntut para pelaku bisnis untuk menciptakan produk yang tak hanya sekedar berkualitas, akan tetapi harus memiliki ciri khas untuk mendapatkan perhatian para konsumen.

Untuk mencapai keberhasilan dalam bisnis, terdapat salah satu aspek yang terpenting yaitu bagaimana pelaku bisnis dalam menjalankan atau memasarkan produknya. Kegiatan memasarkan atau yang biasa disebut promosi merupakan suatu upaya untuk mempromosikan produknya dengan tujuan agar meningkatkan kesadaran konsumen terhadap produk yang dipromosikan sehingga konsumen dapat mengenal produk dan tertarik untuk membeli produk tersebut. Kegiatan promosi ini juga dapat menanamkan ingatan akan produk atau merek kepada para konsumen. Promosi dengan cara yang efektif dan efisien cukup untuk meningkatkan daya saing produk.

\footnotetext{
Kegiatan promosi sebelumnya hanya dilakukan dengan menawarkan produk secara langsung atau mulut ke mulut. Namun dirasa kurang efektif dalam menjalankan promosi sebuah produk. Karena jika hanya menawarkan produk secara langsung maka kurang tersebar luas
}

informasi mengenai produk tersebut dan memungkinkan kurangnya kesadaran dan perhatian para konsumen untuk hanya mengetahui produk maupun melakukan pembelian.

Efektivitas berasal dari kata efektif yang mengandung pengertian dicapainya keberhasilan dalam mencapai tujuan yang telah ditetapkan. Efektivitas dalam kegiatan promosi bisa melalui suatu media. Dalam penelitian ini bagaimana media tersebut bisa efektif dalam mencapai keberhasilan dan tujuan dalam mempromosikan produk melalui bantuan sebuah media

Seiring perkembangan zaman yang semakin pesat terutama dalam bidang teknologi banyak memunculkan temuan baru yang semakin canggih. Perkembangan teknologi sekarang ini didasari atas kebutuhan manusia yang semakin tinggi. Dengan teknologi tersebut dapat mempermudah manusia dalam segala urusan dan tentunya dalam berkomunikasi. Bermunculannya alat teknologi canggih seperti smartphone dapat memberikan kita kemudahan dalam berkomunikasi serta berbagi informasi dengan siapa pun dan dimana pun. Fitur-fitur aplikasi yang ada di smartphone dapat dimanfaatkan sebagai media untuk berkomunikasi dan bertukar informasi, terutama internet atau media sosial. Dengan semakin 
berkembang pesat penggunaan internet maka semakin cepat pula arus perukaran informasi. Hal tersebut membuat manusia era ini cederung lebih sering menggunakan media sosial dalam berkomunikasi dan berinteraksi karena tidak adanya batasan.

Pasar bisnis di Indonesia saat ini sangat dimudahkan dengan hadirnya media sosial. Dengan adanya teknologi canggih seperti sekarang inilah yang dapat dimanfaatkan untuk melakukan kegiatan promosi produk atau merek usaha. Saat ini kegiatan promosi dan penjualan produk tidak perlu mengeluarkan biaya yang tinggi, karena dapat dilakukan melalui internet atau media sosial yang sudah jelas penyebaran informasinya lebih luas dan merata.

Media sosial yang paling banyak digunakan oleh masyarakat Indonesia saat ini adalah Instagram. Instagram merupakan sebuah aplikasi yang memungkinkan penggunanya untuk berbagi foto maupun video. Penggunaannya yang mudah menjadikan Instagram begitu diminati dan populer di berbagai kalangan masyarakat, baik hanya sekedar membagi informasi kegiatan sehari-hati maupun untuk berbisnis.

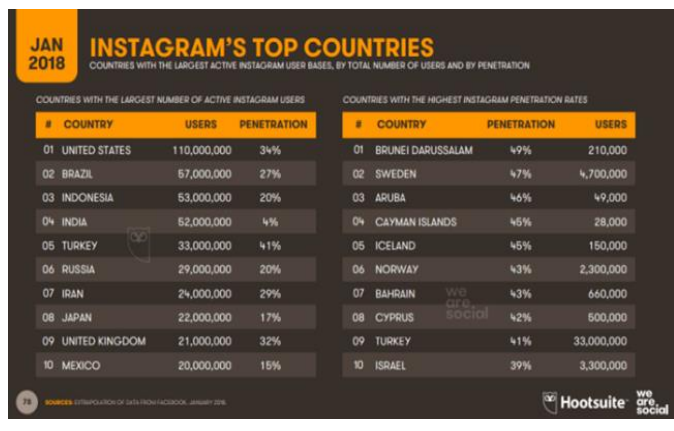

Sumber: jelajahdigital.com

Berdasarkan gambar di atas, menurut hasil survei yang di lakukan oleh We Are Social dan Hootsuite, Negara Indonesia menempati posisi ketiga dari 10 Negara pengguna aktif Instagram sebanyak 53 juta pengguna pada bulan Januari 2018. Jumlah pengguna Instagram akan terus mengalami peningkatan setiap tahunnya.

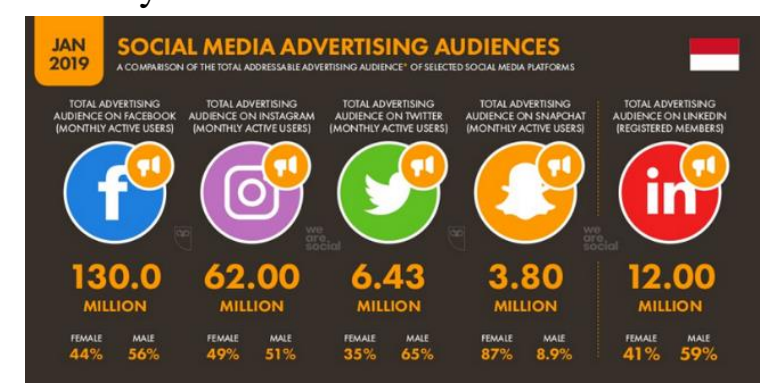

Sumber: tekno.kompas.com

Menurut hasil survei yang telah di lakukan kembali pada bulan Januari 2019 oleh We Are Social dan Hootsuite, jumlah pengguna Instagram di Indonesia cukup meningkat dari sejumlah 53 juta pengguna menjadi 62 juta pengguna pada awal tahun 2019 ini.

Dari data tersebut dapat disimpulkan bahwa pengguna internet di Indonesia semakin 
meningkat jumlahnya terutama media sosial Instagram. Hal tersebut menjadi bukti peluang besar bagi pelaku usaha bisnis terutama di bidang fashion untuk bisa mempromosikan produknya lebih luas melalui Instagram. Karena kini Instagram telah berkembang sebagai media para pembisnis untuk menginformasikan usahanya melalui kegiatan promosi di Instagram. Belakangan ini telah banyak pelaku usaha yang menggunakan media sosial Instagram dalam mempromosikan, memasarkan, dan menjualkan produk mereka kepada konsumen karena dinilai lebih mudah dan praktis dalam menawarkan produk kepada calon konsumen.

Salah satu online shop fashion yang menggunakan Instagram sebagai media promosi adalah Chic Square. Chic Square merupakan online shop yang menawarkan produk seperti hijab dan outfit untuk wanita. Chic Square melakukan promosi secara langsung dengan membuka warehouse dan yang paling utama melalui media sosial Instagram. Chic Square cukup intens dalam kegiatan promosi setiap harinya dengan upload produk terbaru atau hanya dengan share instastory di akun Instagram. Sering kali Chic Square juga mengadakan promosi yang menarik seperti giveaway untuk para followers atau konsumennya dengan memberikan hadiah berbagai macam produk Chic Square untuk pemenang yang terpilih. Dengan harapan bertambahnya jumlah followers, like, dan komentar yang positif setiap harinya tentunya bertujuan agar menarik para konsumen agar membeli produk yang telah di promosikan.

Oleh karena itu dalam penelitian ini peneliti ingin mengetahu seberapa besar penilaian followers terhadap akun Instagram hijab dan outfit Chic Square, seberapa besar Instagram dapat dijadikan sebagai media promosi pada produk hijab dan outfit Chic Square, seberapa besar efektivitas Instagram sebagai media promosi pada produk hijab dan outfit Chic Square.

\section{TINJAUAN PUSTAKA}

\section{A. Landasan Teoritis}

\section{Teori Uses and Gratification}

Teori uses and gratification pertama kali diperkenalkan oleh Herbert Blummer dan Elihu Katz pada tahun 1974 dalam buku yang ditulisnya yaitu The Uses on Mass Communications:

Current

Perspectives on Gratification Research.

Terdapat lima elemen atau asumsi dasar yang mendasari teori uses and gratification ini yaitu:

- Audiens dianggap aktif dan penggunaan media beoriantasi pada tujuan. Artinya, khalayak sebagai bagian penting dari 
penggunaan media massa diasumsikan mempunyai tujuan.

- Inisiatif yang menghubungkan antara kebutuhan kepuasan dan pilihan media spesifik terletak di tangan audiens.

- Media dan sumber-sumber lain bersama-sama memenuhi kebutuhan khalayak.

- Orang-orang memiliki cukup kesadaran atas penggunaan media, ketertarikan dan motif. Hal ini yang membuat para peneliti mendapatkan gambaran lebih akurat atas penggunaan media tersebut.

- Penilaian terhadap isi media hanya dapat dilakukan oleh khalayak tersebut. (Stanley J. Baran and Dennis K. Davis: 2000, 433).

\section{B. Landasan Konseptual}

\section{Komunikasi}

Komunikasi adalah proses yang memungkinkan seseorang (komunikator) menyampaikan rangsangan untuk mengubah perilaku orang lain dan proses penyampaian maupun pengoperan pernyataan ataupun lambang-lambang bermakna untuk memberitahu, mengubah sikap atau perilaku seseorang kepada orang lain baik secara langsung maupun tidak langsung. Komunikasi menurut Carl I. Hovland dapat didefinisikan sebagai berikut, komunikasi adalah proses yang

memungkinkan seseorang menyampaikan rangsangan (biasanya lambang-lambang verbal) untuk mengubah perilaku orang lain. Definisi lain menurut Everett $M$. Rogers, komunikasi adalah proses di mana suatu ide dialihkan dari sumber kepada suatu penerima atau lebih, dengan maksud untuk mengubah tingkah laku mereka. (Mulyana, 2001:62).

\section{Efektivitas}

Efektivitas menurut

Sondang P. Siagian, ialah pemanfaatan sumber daya, sarana dan prasarana dalam jumlah tertentu yang secara sadar ditetapkan sebelumnya untuk menghasilkan sejumlah barang atas jasa kegiatan yang dijalankannya. Efektivitas menunjukkan keberhasilan dari segi tercapai tidaknya sasaran yang telah ditetapkan. Jika hasil kegiatan semakin mendekati sasaran, berarti makin tinggi efektivitasnya. (Siagian, Sondang P. 2002:77).

\section{Media Sosial}

Van Dijk (2013) Media sosial adalah platform media yang memfokuskan pada eksistensi pengguna yang memfasilitasi mereka dalam beraktifitas maupun berkolaborasi. Karena itu media sosial dapat dilihat sebagai medium (fasilitator) online yang 
menguatkan hubungan antara pengguna sekaligus sebagai sebuah ikatan sosial. (Nasrullah, Rulli. 2015:11).

\section{Instagram}

Instagram adalah suatu aplikasi atau alat penyampaian pesan yang dapat digunakan untuk berkomunikasi dengan khalayak secara luas. Instagram adalah sebuah aplikasi yang digunakan untuk membagikan foto dan video. Instagram sendiri masih merupakan bagian dari Facebook. Semakin populernya Instagram sebagai aplikasi yang digunakan untuk membagi foto membuat banyak pengguna yang turun ke bisnis online turut mempromosikan produk-produknya melalui Instagram. (M. Nisrina, 2015:137).

\section{Pemasaran}

Menurut Fandy Tjiptono, pada hakikatnya promosi adalah suatu bentuk kkomunikasi pemasaran. Yang di maksud komunikasi pemasaran adalah aktivitas pemasaran yang berusaha menyebarkan informasi, mempengaruhi atau membujuk, dan mengingatkan pasar sasaran atas produknya agar bersedia menerima, membeli, dan loyal pada produk yang ditawarkan perusahaan yang bersangkutan. (Tjiptono, Fandy. 2001:219).

\section{Produk}

Produk merupakan elemen penting dalam sebuah program pemasaran. Strategi produk dapat mempengaruhi strategi pemasaran lainnya. Pembelian sebuah produk bukan hanya sekedar untuk memiliki produk tersebut, tetapi juga untuk memenuhi kebutuhan dan keinginan konsumen.

Agar produk dapat berhasil, maka haruslah dilakukan penelitian dan pengembanan produk. Dalam buku Indriyo Gito Sudarma memaparkan lima hal yang perlu dikembangkan, yaitu:

- Daya saing produk berdasarkan kualitas

- Produk harus dapat memenuhi kebutuhan riil konsumen

- Produk baru harus dapat berperan positif terhadap produk yang lain

- Produk harus berperan positif terhadap citra perusahaan (coorporate image)

- Hak paten produk.

Produk yang terdiversifikasi serta beraneka ragam, akan membentuk citra positif terhadap perusahaan atau korporasi. Selain itu, hak paten juga perlu dilakukan korporasi atau perusahaan untuk melindungi atau memberi kekuatan pada produk. (Lehman, D.R., \& Winer, R.S. 2005). 


\section{Hipotesis}

Hipotesis dalam penelitian ini adalah sebagai berikut:

$\mathrm{H}_{\mathrm{a}}$ : Terdapat efektivitas Instagram Chic Square sebagai media promosi.

$\mathrm{H}_{\mathrm{o}}$ : Tidak terdapat efektivitas akun Instagram Chic Square sebagai media promosi.

\section{METODOLOGI PENELITIAN}

Penelitian ini menggunakan pendekatan obyektif atau lebih dikenal dengan dengan pendekatan positivisme. Menurut Kriyantono (2012: 54) berdasarkan landasan ontologis, pendekatan obyektif atau pendekatan positivisme merupakan pendekatan yang dapat diukur dengan standar tertentu, digeneralisasi, dan bebas dari konteks dan waktu.

Metodologi yang digunakan
adalah metodologi penelitian kuantitatif. Menurut Sugiyono (2017: 8) penelitian kuantitatif dapat diartikan sebagai metode penelitian yang berlandaskan pada filsafat positivisme, digunakan untuk meneliti pada populasi atau sampel tertentu, pengumpulan data menggunakan instrumen penelitian, analisis data bersifat kuantitatif atau statistik dengan tujuan untuk menguji hipotesis yang telah ditetapkan.
Populasi dalam penelitian ini adalah followers atau pengikut dari akun Instagram Chic Square. Dimana jumlah followers akun Instagram Chic Square yaitu sebesar 27.300 (Sumber: akun Instagram Chic Square pada tanggal 26 April pukul 23:32 WIB). Sehingga jumlah tersebut adalah populasi dalam penelitian ini.

Sedangkan dalam menentukan jumlah sampel peneliti menggunakan teknik simple random sampling, teknik ini adalah teknik pengambilan sampel dari populasi yang dilakukan secara acak tanpa memperhatikan strata yang ada dalam populasi itu. Untuk menentukan sampel yang akan dijadikan responden, peneliti memakai rumus Slovin yakni :

$$
\mathrm{n}=\frac{N}{1+N e} 2
$$

Keterangan :

$$
\begin{aligned}
& \mathrm{n}=\text { Jumlah sampel } \\
& \mathrm{N}=\text { Jumlah populasi } \\
& \mathrm{e}=\text { Kesalahan } 10 \%
\end{aligned}
$$

Sehingga perhitungan penentuan jumlah sampel dalam penelitian ini adalahh:

$$
\begin{aligned}
& n=\frac{27.300}{1+27.300(0,1)} 2 \\
& \mathrm{n}=99,63 \mathrm{n}=100
\end{aligned}
$$

Berdasarkan perhitungan diatas maka hasil pembulatan sampel dalam perhitungan diatas adalah sebanyak 
100. Sehingga sampel dalam penelitian ini yaitu 100 responden.

\section{PEMBAHASAN}

\section{Analisis Deskritptif}

A. Variabel X

$\%=\frac{n}{N} \times 100 \%$

$\%=\frac{4201}{5000} \times 100 \%$

$\%=84,02$

Berdasarkan perhitungan

di atas, variabel akun

Instagram Chic Square

(variabel X) mendapatkan hasil sebesar 84,02 \%. Hal ini masuk ke dalam kriteria sangat baik berdasarkan tabel kriteria analisis deskriptif presentase.

B. Variabel Y

$$
\begin{aligned}
\% & =\frac{n}{N} \times 100 \% \\
\% & =\frac{2911}{3500} \times 100 \% \\
\% & =83,17
\end{aligned}
$$

Berdasarkan perhitungan di atas, variabel promosi produk Chic Square (variabel $\mathrm{X})$ mendapatkan hasil sebesar $83,17 \%$. Hal ini masuk ke dalam kriteria sangat baik berdasarkan tabel kriteria analisis deskriptif presentase.

\begin{tabular}{|c|c|c|}
\hline & & $\begin{array}{l}\text { Unstand } \\
\text { ardized } \\
\text { Residual }\end{array}$ \\
\hline \multicolumn{2}{|l|}{$N$} & 100 \\
\hline \multirow{2}{*}{$\begin{array}{l}\text { Normal } \\
\text { Parameters }\end{array}$} & Mean &, 0000000 \\
\hline & Std. Deviation & 2,522879 \\
\hline \multirow{3}{*}{$\begin{array}{l}\text { Most Extreme } \\
\text { Differences }\end{array}$} & Absolute & 081 \\
\hline & Positive & 081 \\
\hline & Negative &,- 059 \\
\hline \multicolumn{2}{|l|}{ Test Statistic } & 081 \\
\hline \multicolumn{2}{|c|}{ Asymp. Sig. (2-tailed) } & $107^{c}$ \\
\hline
\end{tabular}

\section{Uji Normalitas}

One-Sample Kolmogorov-Smirnov Test

a. Test distribution is Normal.

b. Calculated from data.

c. Lilliefors Significance Correction.
Berdasarkan hasil uji normalitas di atas, menunjukan data normal dengan nilai sign pada kolom Asymp. Sig. (2-tailed) sebesar 0.107. Hasil uji tersebut melebihi angka 0,05, sehingga dapat disimpulkan bahwa data sampel pada variabel $\mathrm{X}$ dan variabel $\mathrm{Y}$ berdistribusi normal dan dihitung menggunakan statistik parametrik.

\section{Analisis Korelasi}

\begin{tabular}{|c|c|c|c|}
\hline \multicolumn{4}{|c|}{ Correlations } \\
\hline & & $\begin{array}{l}\text { Instagra } \\
\text { m }\end{array}$ & Promosi \\
\hline \multirow[t]{3}{*}{ Instagram } & $\begin{array}{l}\text { Pearson } \\
\text { Correlation }\end{array}$ & 1 &, $740^{n \times}$ \\
\hline & Sig. (2-tailed) & &, 000 \\
\hline & $\mathrm{N}$ & 100 & 100 \\
\hline \multirow[t]{3}{*}{ Promosi } & $\begin{array}{l}\text { Pearson } \\
\text { Correlation }\end{array}$ &, $740^{\star x}$ & 1 \\
\hline & Sig. (2-tailed) &, 000 & \\
\hline & $\mathrm{N}$ & 100 & 100 \\
\hline
\end{tabular}

Berdasarkan tabel di atas, dapat dilihat bahwa nilai Sig. (2-

tailed) antara variabel akun Instagram Chic Square (variabel $\mathrm{X})$ dengan variabel promosi produk Chic Square (variabel X) adalah 0,000. Berdasarkan hasil tersebut, maka dapat disimpulkan bahwa antara variabel $\mathrm{X}$ dan $\mathrm{Y}$ berkorelasi karena nilai sinifikansinya lebih kecil dari

\begin{tabular}{|c|c|c|c|c|}
\hline \multicolumn{5}{|c|}{ Model Summary } \\
\hline Model & $\mathrm{R}$ & R Square & $\begin{array}{l}\text { Adjusted } \\
\text { R Square }\end{array}$ & $\begin{array}{l}\text { Std. Error } \\
\text { of the } \\
\text { Estimate }\end{array}$ \\
\hline 1 & $740^{a}$ & .547 & .543 & 2,53572 \\
\hline
\end{tabular}
0,05 .

\section{Koefisien Determinasi}


Berdasarkan tabel di atas, untuk melihat hasil koefisien determinasi dapat dilihat pada kolom nilai $R$ Square yaitu 0,547 . Sehingga dapat dijelaskan bahwa pengaruh variabel akun Instagram Chic Square terhadap variabel promosi produk Chic Square yaitu sebesar $54,7 \%$, sedangkan sisanya yaitu sebesar $45,3 \%$ dipengaruhi oleh faktor-faktor lainnya diluar akun Instagram Chic Square yang tidak diteliti dalam penelitian ini.

\section{Analisis Regresi Linear Sederhana}

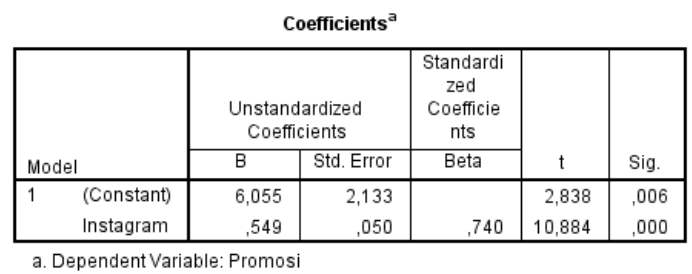

Beradasarkan tabel di atas, dapat diketahui bahwa nilai Constant (a) sebesar 6,055 sedangkan nilai akun Instagram Chic Square (b atau koefisien regresi) sebesar 0,549. Sehingga persamaan regresinya dapat ditulis:

$\mathrm{Y}=\mathrm{a}+\mathrm{bX}$

$\mathrm{Y}=6,055+0,549 \mathrm{X}$

Pada persamaan tersebut dapat dijelaskan bahwa nilai Constant (a) adalah sebesar 6,055. Jika tidak adanya efektivitas akun Instagram Chic Square, maka besar promosi produk adalah 6,055. Sehingga dapat dikatakan bahwa ketika nilai akun Instagram Chic Square bertambah 1\% maka nilai promosi produk bertambah sebesar 0,549. Karena nilai b bentuknya adalah positif, maka menunjukkan bahwa hubungan antar variabel adalah positif.

\section{Uji Hipotesis}

$$
\mathrm{t}=\frac{r \sqrt{n-2}}{\sqrt{1}-r^{2}}=\frac{0,740 \sqrt{100-2}}{\sqrt{1}-\left(0,740^{2}\right)}=10,88
$$

Berdasarkan penghitungan di atas, thitung nya diperoleh sebesar 10,88. Jika melihat $t_{\text {tabel }}$ pada taraf signifikansi $0,05 \%$ dan derajat kebebasan (dk) 98 (n-2), maka diperoleh $t_{\text {tabel }}$ sebesar 1,984. Dengan data tersebut dapat dilihat bahwa $\mathrm{t}_{\text {hitung }} 10,88$ lebih besar dari $\mathrm{t}_{\text {tabel }}$ yaitu 1,984. Sehingga dapat disimpulkan bahwa $\mathrm{H}_{\mathrm{o}}$ di tolak dan $\mathrm{H}_{\mathrm{a}}$ diterima. Hal tersebut diartikan bahwa terdapat efektivitas antara akun Instagram Chic Square (variabel X) sebagai media promosi produk (variabel Y).

\section{KESIMPULAN}

Berdasarkan hasil penelitian dan analisis data yang telah peneliti paparkan sebelumnya, maka peneliti menarik kesimpulannya sebagai berikut:

1. Pada variabel $X$ yaitu akun Instagram Chic Square memilki indikator diantaranya followers atau pengikut, foto, captions atau pesan, like atau suka dan komentar yang telah mendapatkan hasil presentase sebesar 84,02\%. Sehingga akun Instagram Chic Square termasuk dalam kriteria sangat baik. 
Dengan hasil presentase yang telah diperoleh akun Instagram Chic Square menandakan akun tersebut banyak disukai oleh followers khususnya responden karena menarik perhatian khalayak dengan memiliki kualitas unggahan dan produk yang baik serta memberikan rasa kepuasan responden sebagai followers terhadap kebutuhannya dan pemilihan penggunaan media yang tepat.

2. Pada variabel Y yaitu promosi produk Chic Square memiliki indikator diantaranya modifikasi tingkah laku, memberitahu, membujuk dan mengingatkan yang telah mendapatkan hasil presentase sebesar $83.17 \%$. Sehingga promosi produk Chic Square termasuk dalam kriteria baik. Dengan hasil presentase yang telah diperoleh promosi produk yang dilakukan melalui akun Instagram Chic Square baik.

3. Telah dipaparkan bahwa hubungan antara variabel efektivitas akun Instagram Chic Square (variabel $\mathrm{X}$ ) dengan variabel promosi produk Chic Square (variabel Y) adalah sebesar 0,740. Hal tersebut menunjukkan bahwa derajat hubungan antara variabel $\mathrm{X}$ dan variabel $\mathrm{Y}$ bernilai kuat karena berada pada interval 0,060-0,079. Selain itu koefisien korelasi pada penelitian ini juga menunjukkan hasil yang positif, maka kedua variabel mempunyai hubungan yang searah, dalam arti jika variabel $X$ tinggi maka variabel $\mathrm{Y}$ juga akan tinggi. Jika nilai koefisien korelasi sebesar 0,740 dimasukkan ke dalam persamaan koefisien determinasi, maka memiliki hasil sebesar $54,7 \%$. Sehingga dapat dijelaskan bahwa efektivitas variabel akun Instagram Chic Square terhadap variabel promosi produk yaitu sebesar 54,7 \%, sedangkan sisanya yang dipengaruhi oleh faktor-faktor lain di luar akun Instagram Chic Square yang tidak diteliti dalam penelitian ini yaitu sebesar 45,3\%.

\section{SARAN}

Adapun saran-saran yang peneliti berikan setelah melakukan penelitian ini yaitu:

A. Saran Akademis

1. Untuk penelitian selanjutnya diharapkan peneliti lain memperhatikan faktor-faktor lainnya seperti variabel atau indikator, agar dapat menghasilkan hasil dari gambaran yang lebih luas.

2. Teori yang digunakan dalam penelitian ini yaitu teori Uses and Gratifications. Bagi peneliti lain, diharapkan menggunakan teori lainnya sehingga diharapkan penelitian ini dapat dilanjutkan dengan kajian dan pembahasan yang 
lebih dalam yang tidak diteliti dan dijelaskan dalam penelitian ini.

\section{B. Saran Praktis}

1. Diharapkan Chic Square tidak hanya memasarkan produknya melalui media sosial Instagram saja, menggunakan media sosial dan platform lain untuk memperluas promosi produknya.

2. Chic Square harus tetap mengembangkan produk yang telah ada maupun produk yang baru agar khalayak lebih interest oleh produk yang ditawarkan. Mengingat perkembangan zaman yang semakin pesat maka harus menawarkan ide-ide baru dan juga inovatif.

\section{DAFTAR PUSTAKA}

SUMBER BUKU :

Kriyantono, Rachmat. 2012. Teknik

Prkatis Riset Komunikasi.

Jakarta: Kencana.

M. Nisrina. 2015. Bisnis Online, Manfaat Media Sosial Dalam Meraup Uang, Yogyakarta: Kobis.

Mulyana, Dedy. 2001. Ilmu Komunikasi Suatu Pengantar, Bandung: Remaja Rosdakarya. Nasrullah, Rulli. 2015. Media Social (Perspektif Komunikasi, Budaya dan Sosioteknologi), Bandung: Simbiosa Rekatama Media.
Lehman, D.R., \& Winer, R.S. 2005. Product Management. Fourth Edition, New York: McGrawHill International.

Siagian, Sondang P. 2002. Kiat Meningkatkan Produktivitas Kerja, Jakarta: PT. Rineka Cipta.

Sugiyono. 2017. Metode Penelitian Kuantitatif, Kualitatif dan $R \& D$. Bandung: Alfabeta.

Tjiptono, Fandy. 2001. Strategi Pemasaran edisi ke-2, Yogyakarta: Andi.

\section{SUMBER INTERNET :}

jelajahdigital.com

tekno.kompas.com 